\title{
Electronic resources as a means of constructing the learning environment of a children's art school
}

\author{
Olga Popova ${ }^{1, *}$, Anzhela Danilenko ${ }^{2}$, Nadezhda Kosenko $^{3}$, and Svetlana Chernikova ${ }^{4}$ \\ ${ }^{1}$ MBISE "Children's Art School of the City of Belgorod", Belgorod State National Research University, Pobedy str., 77, \\ Belgorod, Russia, olggubareva@yandex.ru \\ ${ }^{2}$ Belgorod State National Research University, Belgorod, Pobedy str., 85, Belgorod, Russia, Danilenko@inbox.ru \\ ${ }^{3}$ Orel State University named after I. S. Turgenev, Orel, Komsomolskaya str., 95, Russia, kosenko@yandex.ru \\ ${ }^{4}$ Orel State University named after I. S. Turgenev, Orel, Komsomolskaya str., 95, Russia, svetlanachernikovaorel@gmail.com
}

\begin{abstract}
The article presents a model of personalized mixed learning for the implementation of programs of general additional education in the field of fine arts. This model is presented through the metaphor of the "space of opportunities", in which the student can choose their own educational trajectory and ways to achieve educational goals. The structure of the personalized educational space is slated, the role and place of information and communication technologies in the implementation of personalized education are considered. The key elements of the model presented by us were goal-setting, criteria-based evaluation of the results of educational activities and the use of information and communication technologies. Within the framework of the proposed approach to goal-setting, the transition from simple knowledge and skills to more complex ones is carried out, as well as the synthesis of mental operations with a specific application and creative rethinking of the acquired knowledge. Criteria-based evaluation is intended to provide high-quality feedback. It is carried out on the principles of equality; personalization; clarity of criteria; evaluation of the result, not the activity of the child in the lesson; continuity. The main characteristics of the presented model are: level-based, result-oriented, interactive, and variable.
\end{abstract}

\section{Introduction}

One of the factors that can provide the effective development of the modern education system is its personalization. Today, countries with effective educational systems are actively developing models of mass personalized learning. In the Russian Federation, attempts to create personalized learning models aimed at meeting the educational needs of comprehensive school students and allowed them to independently determine the learning strategy are also being made [1].

\section{Problem Statement}

However, in the Russian Federation at the present phase, there are no models and strategies for personalized learning for the implementation of additional educational programs in the field of fine arts.

\section{Research Questions}

Programs of additional education, including in the field of fine arts, have significant specifics that distinguish them from the syllabuses developed for comprehensive schools. This specificity is due to the personality- oriented approach that underlies the art education system, the close interaction of the student and the teacher in the learning process, and the creative nature of artistic activity. Is it possible to develop a model of personalized distance learning for general development programs in a children's art school taking into account this specificity?

3.1 What is the structure of the personalized learning model for the implementation of additional education programs in the field of fine arts?

3.2 By what technologies can this model be implemented in institutions of additional education of children?

\section{Purpose of the Study}

The purpose of our research is development and approbation a model of personalized learning for the implementation of additional education programs in the field of fine arts for children's art schools.

4.1 Achieving this goal requires solving a number of research tasks:

- Definition of the basic principles of creating a personalized learning model for additional education programs in the field of fine arts;

\footnotetext{
* Corresponding author: e.malushko@volsu.ru
} 
- Definition of the structure of the personalized educational space, its system-forming elements.

\section{Research Methods}

The methodological basis of the work was the research of P. N. Kirilov, N. I. Koryakina, T.Wanner, E.Palmer, K. Turvey, M. Hayler, M.Virvou [2-4]. Based on the study of their work, we identified the key factors of personalization of learning: criteria-based evaluation and mixed learning. Criteria-based evaluation is based on the comparison of the actual achievements of the child with his previous achievements with the predominance of formative and ascertaining evaluation and the level approach, as well as the presence of evaluation as an educational activity (self-assessment). Mixed learning is a technology for organizing the educational process based on combining traditional and e-learning, taking into account new didactic opportunities due to the use of information and communication technologies. The preferred form of implementation of the mixed learning model is an inverted classroom, in which there is a change of working areas: at home, the student gets acquainted with the educational material, and in the classroom, the practical training of the acquired knowledge is carried out. When developing a model of personalized learning for the development of additional educational programs in the field of fine arts, we also relied on the ideas of the constructivist approach [5-6]. The essence of this approach is the idea that knowledge can not be "transmitted" in a ready-made form, the child receives it on the basis of existing experience in the process of educational activities based on the search and solution of problems that are important to him. The constructivist approach is based on the attitude to active cognitive activity of students, to gain knowledge in the process of active goal-setting, search and solution of significant problems for them. The role of the teacher in this case is to guide and regulate this activity. The constructivist approach is associated with significant shifts in the established paradigm of education. This is, firstly, a shift in the content of education, in which the emphasis is shifted from the knowledge component ("I know what") to the activity component ("I know how"). Secondly, the transformation of the form of education, as a result of which the emphasis is shifted from learning as a process where the student is the object, to educational activities in which the student is the subject. Thirdly, there is a shift in the position of the teacher: if previously the teacher acted as a translator of knowledge and mentor, then with the constructivist approach, his role is the role of the organizer of activities.

Methodologically significant for us is the concept of skills of the 21 st century, which states the need to develop not only subject, but also meta-subject skills, the key among which are the so-called " $4 \mathrm{C}$ ": communication, collaboration, creativity, critical thinking. When developing a personalized learning model for the development of additional educational programs in the field of fine arts, we also relied on a system-activity approach, in which the transition from passive learning to active learning activities is carried out and the relationship between planned results and evaluation is emphasized.

Based on the methodological basis of the research, we have developed a model of personalized learning, which is focused on creating a space of opportunities for students, in which they can independently set goals, make choices, and reflect on the results obtained.

\section{Findings}

The key elements of the presented model were goalsetting, which allows to structure the learning goals according to the levels of complexity of educational and cognitive tasks, criteria-based evaluation of the results of educational activities and the use of information and communication technologies.

\subsection{Goal-setting}

The proposed model is based on the modular principle of implementing educational programs and the principle of goal-setting levels. The system of goals of the proposed model is based on the taxonomy of R. Marzano [7] according to which three areas of knowledge are distinguished - information, mental operations, and physical operations. Based on the taxonomy of $\mathrm{R}$. Marzano, we structured the learning goals into four levels. These are the levels of obtaining information, mastering information, applying the acquired knowledge, and forming meta-subject skills. Goalsetting is based on the principle of clarity of goals for the child. This principle allows us to realize the position of the student as a subject in relation to the learning goals. The goals are presented in the form of statements formulated on behalf of the student in the activity form ("I will be able to recognize", "I will be able to portray") and taking into account the SMART criteria.

Table 1. Levels of goal-setting module 


\begin{tabular}{|c|c|c|c|c|c|}
\hline \multicolumn{3}{|c|}{ Level } & Level name & $\begin{array}{l}\text { Specifics of } \\
\text { educational }\end{array}$ & $\begin{array}{l}\text { Examples of the } \\
\text { formulation of educational }\end{array}$ \\
\hline $\begin{array}{l}\text { Meta- } \\
\text { subject }\end{array}$ & $\begin{array}{c}\text { Advance } \\
\mathrm{d}\end{array}$ & Level 4 & $4 \mathrm{~K}$ skills & $\begin{array}{l}\text { Transfer of } \\
\text { knowledge and } \\
\text { skills to another } \\
\text { area }\end{array}$ & $\begin{array}{c}\text { I apply the acquired } \\
\text { knowledge in my creative } \\
\text { activity }\end{array}$ \\
\hline \multirow{3}{*}{ Subject } & \multirow{3}{*}{ Basic } & Level 3 & $\begin{array}{c}\text { Physical } \\
\text { operations }\end{array}$ & $\begin{array}{l}\text { Readiness to } \\
\text { apply the eamed } \\
\text { elements in } \\
\text { practice }\end{array}$ & $\begin{array}{l}\text { I can create (compose) an } \\
\text { imaginary (conditionall still- } \\
\text { life and choose a palette of } \\
\text { colors for it with basic } \\
\text { colors }\end{array}$ \\
\hline & & Level 2 & $\begin{array}{c}\text { Mental } \\
\text { operations }\end{array}$ & $\begin{array}{l}\text { Understanding } \\
\text { and assimilation } \\
\text { of elements }\end{array}$ & $\begin{array}{l}\text { I can graphically represent } \\
\text { the history of coloration } \\
\text { development of describe in } \\
\text { an essay about coloration } \\
\text { development from ancient } \\
\text { paintings to the application } \\
\text { of basic colors in a painting. }\end{array}$ \\
\hline & & Level 1 & Information & $\begin{array}{l}\text { Non-mechanical } \\
\text { assimilation of } \\
\text { material and its } \\
\text { remroduction }\end{array}$ & $\begin{array}{l}\text { I can choose works whose } \\
\text { coloration is based on basic } \\
\text { colors. }\end{array}$ \\
\hline
\end{tabular}

Within the framework of this approach to goalsetting, the transition from simple knowledge and skills to more complex ones is carried out, as well as the synthesis of mental operations with a specific application and creative rethinking of the acquired knowledge. Structured goals are an integral part of a personalized learning model for additional general education programs in the field of fine arts. They allow us to solve a number of important tasks. Firstly, to provide a choice at the basic level and the ability to choose between the basic and advanced levels. Secondly, to provide guidelines for the educational activities of the student with less dependence on the teacher. Thirdly, to provide a methodological basis for the teacher, who will be able to offer students interchangeable tasks.

The subject content is structured into training modules lasting 4-6 hours. Learning within the framework of the module is based on the principle of an inverted class: theory is studied at home ( 2 hours are allocated for it), practical skills are practiced in the classroom (2 hours), for those students who have chosen an advanced level, an additional task is provided, which is performed at home and at school (1-2 hours).

Individual educational trajectory is provided through the variability of tasks. The tasks are designed in such a way that the child can choose the source of information (text, video and audio), the type of educational activity, the forms of control over the assimilation of theoretical material, and the forms of work. A student who has completed a level earlier than planned can use the free time to study an additional module on the development of softskills - flexible skills.

Tasks are designed in such a way that in the process of their implementation, flexible skills of the groups "thinking" (exploring the world, discovering new things, solving problems), "interaction with others" (acting in a team), "interaction with myself" (understanding myself, managing myself) are developed. At the heart of this approach is the "soft through hard" - the attitude that the subject content is not an end in itself, but a tool for developing social skills and experience.

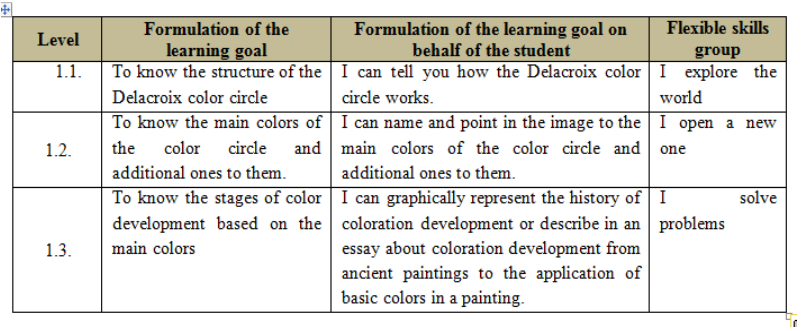

In accordance with the SMART goal-setting technology, the formulated goals should meet several criteria: specificity, measurability, achievability, relevance, and time-bound. Therefore, in the process of goal-setting, it is necessary to avoid generalized formulations of educational goals, such as "develop a sense of beauty" (the criterion of measurability is violated); "draw a landscape" (the criterion of specificity is violated - the volume of the material being studied and the nature of actions are unclear); "perform an exercise" (the criterion of relevance is violated - the formulation contains a teaching method, while it is unclear why you need to perform the exercise, because the educational result is not the fact of performing the exercise, but the knowledge, abilities, skills obtained).

The goals of all four levels should be connected logically, if at level 1 a simple subject result is formulated, then at level 4 it should be integrated into a more complex, meta-subject result.

\subsection{Criteria-based evaluation}

Criteria-based evaluation is intended to provide highquality feedback. Within the framework of the proposed program, it is carried out using distance and e-learning technologies, which saves the teacher time for interacting with students. Level 2 tasks published on the e-learning platform are evaluated automatically or are provided with evaluation schemes (rubricators), which allows self-testing. At the end of each module, willing students present the results of their work on Level 4.0 tasks to the class and receive feedback. Feedback can also include formative evaluation - the current, frequent evaluation of the work performed, which allows the student to understand whether he has achieved the goal and quickly adjust his work, and the teacher to understand the student's educational position. This evaluation is carried out within the framework of performing creative work in practical classes.

Planned types of evaluation:

- current subject evaluation (records the percentage of tasks completed within the module);

- final subject evaluation (individual verification of the achieved subject results at the end of the development of the training module / group of modules).

A level is considered completed when the student demonstrates the grounds for achieving it by completing the corresponding tasks. 


\begin{tabular}{|c|c|c|c|}
\hline Evaluation criteria & l & 2 & 3 \\
\hline $\begin{array}{c}\text { Volume of completed } \\
\text { tasks }\end{array}$ & $\mathrm{x}$ & $\mathrm{x}$ & $\mathrm{x}$ \\
\hline $\begin{array}{c}\text { Volume of } \\
\text { educational material }\end{array}$ & $\mathrm{x}$ & $\mathrm{x}$ & $\mathrm{x}$ \\
\hline $\begin{array}{c}\text { Volume of work on } \\
\text { the assimilation of } \\
\text { educational material }\end{array}$ & $\mathrm{x}$ & $\mathrm{x}$ & $\mathrm{x}$ \\
\hline
\end{tabular}

Criteria-based evaluation is intended to provide high-quality feedback. It is carried out on the principles of equality; personalization; clarity of criteria; evaluation of the result, not the activity of the child in the lesson; continuity. Within the framework of the proposed programme, criteria-based evaluation is carried out using distance and e-learning technologies, which saves the teacher time for interaction with students.

\section{Conclusion}

Thus, the key elements of the model presented by us were goal-setting, criteria-based evaluation of the results of educational activities and the use of information and communication technologies. The model is based on the principle of modular learning, the implementation of which represents the movement of the student to the educational goal through the achievement of a certain result formulated in accordance with the SMART goalsetting technology (specific, measurable, achievable, relevant, time bound). The main characteristics of the presented model are: level-based, result-oriented, interactive, and variable. This model is intended for implementation in children's art schools and schools of art.

\section{References}

1. P. Kirilov, \& N. Korjakina, School of opportunities. Individual trajectories of development. (2018), URL: https://edpolicy.ru/school-of-opportunity(date of access: 16.03.17)

2. K. Turvey, \& M. Hayler, Teaching and Teacher Education 68, 42-52(2017).

3. M. Virvou \& E. Alepis, Computers \& Education 44(1), 53-68 (2005)

4. T. Wanner, \& E. Palmer, Computers \& Education 88, 354-369 (2015)

5. N.Özkarsl1, \& A. Gürdal, Procedia - Social and Behavioral Sciences 2 (2), 3965-3970

6. Q. Zhang, \& Q. Kou, Physics Procedia 25, 22942297 (2012).

7. R.J. Marzano, Designing a new taxonomy of educational objectives (Thousand Oaks, CA: Corwin Press, 2000) 